\title{
Persepsi Publik terhadap Tokoh Politik dalam Debat Politik di Kanal Youtube
}

\author{
Khristianto \\ Universitas Muhammadiyah Purwokerto, Purwokerto, Indonesia \\ Email: Kristian.topz@gmail.com
}

\begin{tabular}{|c|c|}
\hline Article Info & ABSTRACT \\
\hline Article history: & \multirow{6}{*}{$\begin{array}{l}\text { This study is aimed at revealing the perception of the public over } \\
\text { some politicians, particularly those involving in political debates } \\
\text { broadcasted by TV stations, then their videos are uploaded in } \\
\text { Youtube. The data are their coments on the politicians and their } \\
\text { performances in the debates which usually presented peoples from } \\
\text { contesting parties in the presidential election. The data were then } \\
\text { analyzed using Appraisal theory (Martin \& White, 2005), and } \\
\text { interpreted through a perspective of discourse strategy (van Dijk, } \\
\text { 2001). The finding has proved that the judgment is the most } \\
\text { dominant appraisal elements (86\%) employed by the public in } \\
\text { evaluating the politicians' behaviors in the debates. From a } \\
\text { comparison, it seems that the incumbent people were evaluated } \\
\text { better than the competitor. In general, the public from both } \\
\text { contestants prefer to emphasize the other's negative side. }\end{array}$} \\
\hline Submitted Dec 28, 2019 & \\
\hline Revised Feb 19, 2020 & \\
\hline Published Oct 30, 2020 & \\
\hline Keywords: & \\
\hline $\begin{array}{l}\text { Perception of the public } \\
\text { Presidential election } 2019 \\
\text { Appraisal } \\
\text { Discourse strategy }\end{array}$ & \\
\hline
\end{tabular}

\section{Corresponding Author:}

\section{Khristianto,}

Fakultas Sastra, Universitas Muhammadiyah Purwokerto

Jalan Raya Dukuhwaluh, Kembaran, Purwokerto, Indonesia

Email: Kristian.topz@gmail.com

\section{PENDAHULUAN}

Politik selalu menjadi sorotan publik, apalagi ketika publik juga memiliki peran di dalam peristiwa politik itu. Satu-satunya ruang politik di mana publik secara keseluruhan "berperan" dan menjadi "penentu" adalah pemilihan kepala (pemerintahan), baik di tingkat desa, kabupaten, propinsi, maupun tingkat pemerintahan pusat baik untuk memilih para wakil rakyat atau pun kepala pemerintahan. Dalam pesta demokrasi tersebut, rakyat menjadi "pemain" politik yang menentukan siapa yang akan menduduki kursi-kursi perwakilan atau pun kepala daerah.

Sebagaimana tak bermarkahnya, para pemain politik tersebut bukan hanya terlibat dengan memberikan suaranya dengan "mencoblos" pada hari pemilihan, tetapi seringkali terlibat secara emosional dan bahkan sebagian menjadi bagian dari "panitia" pemenangan. Keterlibatan itu makin kuat ketika isu politik itu tercampur dengan isu agama-seperti yang tampak pada pemilihan presiden 2019. Tidak bisa dipungkiri, sentimen keagamaan yang ditinggalkan oleh kasus "penistaan agama" yang menyeret Ahok masih mewarnai perhelatan politik di waktu itu. Akibatnya, muatan emosional terkait pilihan politik pun terasa kuat dan sulit sekali diurai. Media sosial menjadi ajang "pertarungan wacana" di antara mereka yang berbeda pilihan. 
Salah satu wujud pertarungan wacana publik dalam pilpres 2019 tersalurkan dalam kolom komentar Youtube untuk video-video dari tokoh-tokoh politik dari dua kubu yang bertarung, yakni kubu 01 dan 02. Komentar-komentar itu merupkan bentuk persepsi atau penilaian publik terhadap penampilan sang tokoh di televisi, yang kemudian ditambatkan melalui kanal-kanal Youtube, baik kanal resmi stasiun TV itu ataupun kanal-kanal yang lain. Tentu saja persepsi terhadap penampilan tokoh itu juga dipengaruhi oleh pilihanpilihan politik yang sudah terbentuk sebelumnya, meski bisa saja persepsi itu merupakan penilaian netral dari individu yang belum menentukan pilihannya.

Kajian ini dilakukan untuk menilai secara obyektif tentang persepsi publik terhadap pihak kubu 01 dan 02 dengan menerapkan teori Appraisal. Kajian ini akan melacak ulang komentar yang terkait dengan wacana politik yang menjadi pokok pembicaraan. Beberapa kajian appraisal juga pernah dilakukan terhadap wacana-wacana politik di media baik dalam maupun luar negeri (Sukma dkk, 2018, Kamal, 2017, dan Chamidah, 2018). Masingmasing menerapkan salah satu unsur dari sistem appraisal (Martin \& White, 2005), dari aspek judgment (Sukma dkk, 2018), affect (Chamidah, 2017), dan judgment dan graduation (Kamal, 2017).

Semua kajian tersebut berfokus pada sumber penilaian dari represented participants baik dari pemilik media (Kusuma, 2018) dan pelibat wacana (Chamidah, 2017) atau pun jurnalis sebagai penulis (monogloss) (Chamidah, 2017) yang memiliki otoritas penuh terhadap teks. Dilihat dari tempat peristiwanya, masing-masing kajian fokus pada lokasi yang berbeda-beda, dari yang sangat lokal, Bogor (Kusuma, 2018) dengan media wacana berupa banner (kain rentang) untuk materi kampanye, Indonesia (Kamal, 2017) dari sumber data media cetak (Jakarta Post) dengan isu nasional, hingga konteks global (Chamidah, 2018), dengan media CNN dan isu perang Israel-Palestina.

Kajian ini mengangkat objek yang berbeda dengan kajian-kajian sebelumnya, yakni sumber appraisal (appraiser) yang bersifat heterogloss yakni warga net dan yang dinilai (appraised) adalah tokoh-tokoh politik yang terlibat dalam kancah pemilu 2019. Warga net dapat dipandang sebagai sumber penilaian yang genuine dan otentik karena mereka menyampaikan penilaian secara spontan berdasarkan persepsi mereka terhadap penampilan para tokoh politik di media-dibandingkan misalnya dengan jurnalis (berita) atau pun wacana yang muncul dari tokoh politik (kain rentang kampanye). Karena itu, kajian ini penting dilakukan untuk memahami fenomena pemilu dari aspek wacana akar rumput.

\section{TEORI DAN METODOLOGI}

Teori yang menjadi perangkat analisis utama adalah teori Appraisal dari Martin dan White (2005). Teori ini akan dibahas sekilas dengan menyorot pokok-pokok teori yang akan diterapkan dalam analisis data dalam artikel ini. Pembahasan ini akan diikuti dengan paparan metode kajian.

\subsection{Teori Appraisal}

Teori Appraisal termasuk dalam sistem makna interpersonal dari teori SFL Halliday. Ia adalah sub-cabang dari register, yang terdiri atas field, mode, tenor. Appraisal ini masuk pada salah satu cabang tenor, yakni status, affect, contact-yang ketiganya semuanya fokus pada aspek interpersonal dan appraisal lahir dari sub-cabang affect tersebut. Ia berfokus pada penilaian positif/negatif terhadap para pelibat yang ada dalam wacana. Dal hal ini, pelibat ini melingkupi pelibat yang ada dalam teks (represented participants) atau pun pelibat yang berhubungan di luar teks (interactive participants), dan bahkan relasi pelibat dalam dua kategori tersebut (Kress \& Leeuwen, 2006:43). Tampaknya komentar 
publik terhadap video ini lebih mencerminkan relasi yang ketiga; publik tidak berada dalam teks, dan mereka memberikan penilaian terhadap tokoh dalam teks atau pun mereka/kelompok yang berhubungan dengan tokoh yang ada dalam teks.

Sistem penilaian Appraisal ini terbagi tiga yakni afektif (affect), penilaian (judgement), dan apresiasi (appreciation) (Martin and White, 2005:42). Sebagaimana dijelaskan mereka, bahwa sistem appraisal ini melibatkan tiga wilayah makna, yang secara tradisional disebut dengan emosi, etika, dan estetika. Emosi atau perasaan merupakan pusat dari penilaian karena emosi adalah sumber ekspresi yang secara alami kita bawa sejak lahir. Oleh penggagas teori, unsur emosi ini disebut dengan affect, yang secara mudah diterjemahkan menjadi aspek "afektif", yang berkutat pada sikap suka atau tidak suka dengan semua varian dan gradasinya. Mereka menyebutkan bahwa etika atau judgment dan apresiasi itu hanyalah bentuk perasaan atau emosi yang terlembaga sebagai

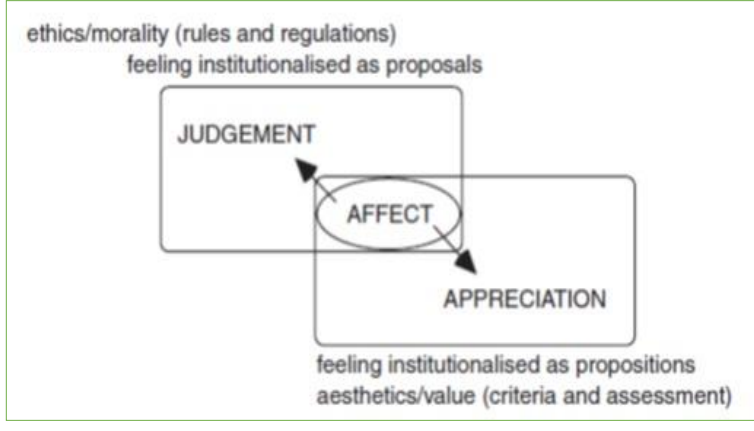

Gambar 1 Sentralitas Afek

kehendak (proposal), sementara apresiasi adalah emosi yang terlembaga dalam bentuk pernyataan (proposisi).

Penilaian (judgement) berkaitan dengan sikap kita terhadap perilaku; kita bisa menghargai, mengkritik, memuji atau sebaliknya mengutuk (Martin and White, 2005:42). Judgement mengoperasionalkan ulang dalam ranah tata aturan dari perilaku-apa yang seharusnya dilakukan atau tidak; sebagian dari tata aturan ini kemudian terformatkan dalam bentuk aturan dan undang-undang yang diberlakukan oleh lembaga agama dan negara (Martin and White, 2005:42). Sebagian lainnya hanya menjadi norma, konvensi dan kepantasan etika yang dibagi bersama oleh anggota budaya tertentu, baik dalam lingkup yang paling sempit hingga yang paling luas.

Sementara itu, apresiasi (appreciation) melibatkan evaluasi fenomena semiotik atau pun alamiah, berdasarkan kaidah penilaian yang sesuai dengan bidangnya. Berbeda dengan judgement, apresiasi mewujudkan ulang perasaan dalam bentuk proposisiproposisi tentang nilai "sesuatu" - apakah sesuatu itu bermanfaat atau sebaliknya; sebagian apresiasi ini di masyarakat terlembaga dalam sistem penghargaan (harga, tingkat, hibah, hadiah, dan penghargaan-penghargaan serupa) (Martin and White, 2005:42). Apresiasi lebih merujuk pada nilai-nilai kebendaan di luar manusia itu sendiri, berbeda dengan judgment yang obyeknya adalah perilaku manusia. Meskipun, hal atau sesuatu itu juga terkait dengan manusia baik langsung atau pun tidak langsung.

\subsection{Metode kajian}

Data dalam kajian ini adalah komentar bagian kolom komentar dari laman media sosial Youtube, sebagai sumber data, yang berisikan video yang terkait dengan isu-isu yang relevan baik dari segi topik maupun waktu serta tokoh yang terlibat. Adapun video yang dimaksud adalah dua video yang berisi perdebatan antar-tokoh yang mewakili kubu 01 
dan kubu 02. Yang pertama adalah DEBAT PANAS! Adian Napitupulu vs Gamal Albinsaid Soal Jokowi\&Prabowo | Dua Sisi dari kanal Talk Show tvOne, yang diunggah padaMar 28, 2019. Sebagaimana tampak dari judul, tokoh politik dari petahana adalah Adian Napitupulu (AN), dan dari pihak 02 adalah Gamal Abinsaid. Sedangkan video yang kedua adalah debat yang mempertemukan Rocky Gerung (RG) dan Budiman Sudjatmiko (BS), diunggah oleh kanal CNN Indonesia pada 25 Oktober 2018, dengan judul Debat Rocky Gerung vs Budiman Sudjatmiko Bicara Politik Bohong di Ruang Publik.

Data dikumpulkan dengan metode simak dan catat (Sudaryanto, 2015), yakni dengan mencermati komentar dan menyalin serta menempelkan bagian-bagian komentar yang dipilih sesuai kriteria, yakni mengandung leksis yang emotif baik langsung atau pun tidak langsung. Dalam proses simak catat tersebut, kajian ini juga menggunakan perangkat lunak leksikografer, Antconc3.2.3w-yang digunakan untuk mengidentifikasi beberapa kata kunci, sebaran, dan klusternya. Teknis analisis datanya menerapkan metode padan referensial, karena alat penentunya adalah fenomena di luar bahasa (Sudaryanto, 2015). Data-data tersebut dikategorikan berdasarkan teori sistem Appraisal (Martin \& White, 2005). Terakhir data ini diuraikan dalam kerangka kajian analisis wacana kritis, AWK (van Dijk, 1985). Sumarlam (2019) menjelaskan bahwa kerangka analisis AWK selalu melibatkan 3 tahapan, yakni analisis linguistik, interpretasi berdasarkan konteks peristiwa wacana, dan eksplanasi, yang mengkaitkan data-data bahasa dan penafsiran konteksnya dengan situasi sosial-budaya yang melingkupi wacana itu.

\section{HASIL DAN PEMBAHASAN}

Bagian ini akan menguraikan temuan-temuan yang terkait dengan persepsi publik terhadap tokoh-tokoh politik baik yang mendukung kubu petahana (01) maupun mereka yang memberikan pembelaan terhadap kubu penantang (02) dalam kancah Pilpres 2019. Masing-masing kubu diwakili oleh dua tokoh, yakni Budiman Sudjatmiko dan Adian Napitupulu untuk kubu petahana, dan Rocky Gerung dan Gamal Abinsaid untuk kubu penantang. Untuk memudahkan pembahasan, penyajian akan dimulai dari persepsi publik terhadap tokoh-tokoh politik kubu petahana.

\subsection{Persepsi Publik terhadap Tokoh Politik Kubu 01}

Figur pertama yang merupakan tim kampanye Jokowi, TKN, adalah Budiman Sudjatmika (BS), yang berhadapan dalam acara Talk Show dengan Rocky Gerung. Ia mendapatkan poin positif pada ketiga aspek appraisal, afektif, judgement maupun apresiasi. Tidak ada satu pun komentar yang bernada negatif terhadapnya. Beberapa contoh komentar-komentar tersebut disajikan dalam tabel 1 berikut.

Tabel 1. Ungkapan persepsi publik terhadap Budiman Sudjatmika

\begin{tabular}{|l|l|l|}
\hline \multicolumn{1}{|c|}{ Afektif } & \multicolumn{1}{|c|}{ Penilaian } & Apresiasi \\
\hline Jagoan reformasi saya & Pahlawan reformasi & Komunikasinya tertata baik \\
Sehat terus & Bernalar cerdas & Gerakan yg real \\
Panutanku & The winner & \\
Respect, Salut & Mantap, mantan aktivis joss & \\
Saya mengagumi & the best, terlalu jenius & \\
Andalan gue & Doktor, hebat & \\
Applause & Mentaruhkan nyawa & \\
& & \\
& & \\
\hline
\end{tabular}

BS memang sudah dikenal semenjak perjuangan reformasi 1998, saat ia masih menjadi aktivis mahasiswa yang menentang rezim kekuasaan Soeharto, orde lama, yang 
sangat kuat dan hampir tidak tergoyahkan. Fakta ini yang ia manfaatkan saat berhadapan dengan RG, yang menjadi selebritis baru dalam pertunjukan wacana politik di media televisi. RG sangat pandai berkata-kata dan bermain logika; ia juga sangat berani mengkritik pemerintahan Jokowi. BS menegaskan bahwa apa yang RG lakukan hanyalah sekedar bermain kata-kata dan logika. Tampaknya RG memang tidak dapat berkelit dari jeratan logika yang dimainkan oleh BS. Akibatnya, respon publik sangat luar biasa; hampir semuanya merespon negatif terhadap RG dan memberikan tanggapan positif terhadap BS-tentu hal ini tidak terlepas dari kecondongan pilihan politik mereka yang sudah ada. Namun dengan fakta obyektif yang mereka tonton dari video, penonton memang akan lebih mudah merespon negatif pada RG dan positif terhadap BS-tanpa perlu memaksakan logika. Pilihan politik yang berlawanan mungkin berakibat pada keengganan untuk merespon, atau memberikan komentar yang datar saja.

Penilaian yang muncul hampir semuanya dikaitkan dengan sejarah peran BS dalam gerakan reformasi di Indonesia, yang efeknya kemudian publik bertanya-tanya, kira-kira di mana RG pada masa itu-yang makin menghempaskan kedigdayaan wacana RG. Komentar-komentar publik pun terpolarisasi pada sosok BS dan perannya pada perjuangan reformasi 98. BS dipersepsikan sebagai orang yang telah melakukan aksi, perjuangan, dan keberanian yang nyata, setidaknya melalui reformasi itu.

Tampak dari gambar 2, BS disebut dengan label-label terkait dengan gerakan reformasi 98, pejuang, pahlawan, aktivis, tokoh, anak, legenda, dan juga jagoan. Penilaian fakta ini juga sejalan dengan fakta obyektif dari perdebatan yang ditampilkan oleh BS. BS memang berada di atas angin di hadapan RG. Hal ini tampak dari komentar-komentar yang merujuk pada proses perdebatan itu, seperti winner, mantap, the best, terlalu jenius, cerdas dan semacamnya, yang ditujukan pada BS. Semuanya itu menunjukkan judgement yang positif terhadap sosok dan perilaku (keterampilan) debat dari BS, sebagaimana disebut oleh Martin dan White (2005:52) bahwa salah satu unsur penilaian ini adalah capacity, "bagaimana kapasitas atau kemampuan seseorang." Ungkapan-ungkapan tersebut merefleksikan asosiasi kapasitas yang tinggi dari subyek yang dirujuk.

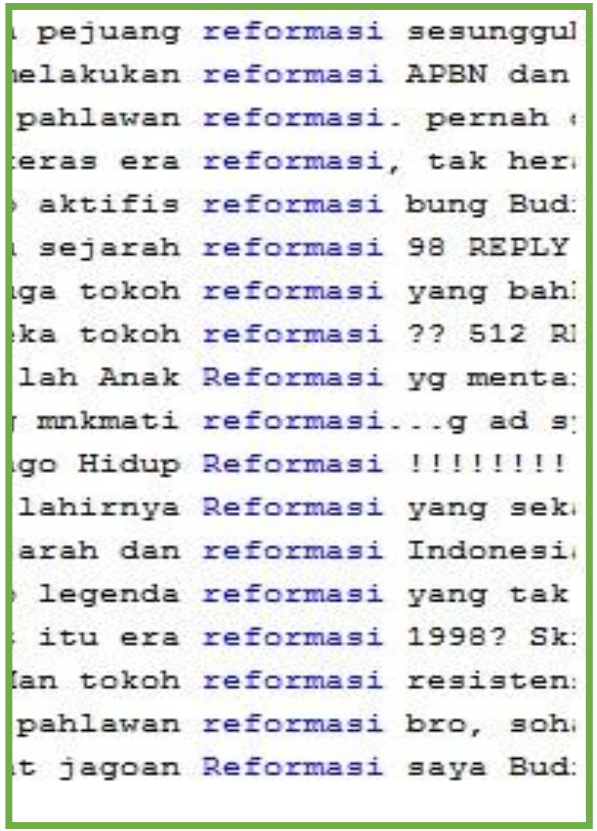

Sementara itu

dari aspek afektif, tanggapantanggapan senada juga terlihat. Warga net menyatakan kekaguman, rasa hormat, dan ekspresi tidak langsung yang bermakna positif. Mereka memperlihatkan afeksi yang 
menyatakan inclination, security dan happiness (Martin \& White, 2005:51), dengan ungkapan-ungkapan jagoan reformasi saya, panutanku, andalan gue, respect, salut dan sebagainya. Kata applause merupakan ungkapan tidak langsung dari rasa kagum, admire; tepuk tangan adalah ekspresi gesture untuk menyatakan kekaguman dan penghormatan. Fakta-fakta ini menegaskan adanya evaluasi yang positif di kalangan publik terhadap BS.

Tim sukses Jokowi berikutnya adalah Adian Napitupulu (AN); ia merupakan salah satu anggota tim sukses yang paling sering tampil di media. Adapun video yang dikaji adalah perdebatan AN dengan tim sukses Prabowo, Gamal Abinsaid (AN). Tampaknya AN adalah anggota TKN yang apes dalam hal persepsi publik ini. Tentu, publik tidak semata melihat sosok secara fisik, tetapi juga menjadi pengamat debat yang obyektif. Perilaku yang tidak berterima bagi publik akan tercermin dari komentar-komentar yang munculterlepas dari pilihan politik mereka. Perilaku orang-dalam hal ini para tokoh yang berdebat-adalah pemicu (Trigger) bagi reaksi atau emosi publik sebagai Emoter, yang menuangkannya melalui kolom komentar (Martin \& White, 2005:46).

Di antara aspek appraisal, yang teridentifikasi paling dominan adalah judgement, penilaian. Terdapat ekspresi-ekspresi afektif yang jumlah tidak terlalu banyak, dan tampak berimbang antara negatif dan positif. Sementara dari aspek judgement itu, hampir seluruh komentar (85\%) merupakan penilaian yang negatif, dan bila ditotal dengan aspek afektif yang negatif, maka ada $91 \%$ persepsi publik yang negatif terhadap penampilan AN dalam debat tersebut, sisanya cenderung positif dalam jumlah yang sangat kecil.

Tabel 2. Ungkapan persepsi publik terhadap Adian Napitupulu

\begin{tabular}{|l|l|}
\hline \multicolumn{1}{|c|}{ Afektif } & \multicolumn{1}{c|}{ Penilaian } \\
\hline $\begin{array}{l}\text { Basi, Ngakak, Miris, Muka } \\
\text { ga enak, Ga berfaedah, } \\
\text { Muak }\end{array}$ & $\begin{array}{l}\text { Gigi, bacot, samaotaknya, } \\
\text { samabrantakannya } \\
\text { Males dengerin }\end{array}$ \\
& $\begin{array}{l}\text { Sakit ini orang, Otak dangkal } \\
\text { Penjilat, Pasien, Sakit jiwa }\end{array}$ \\
& Preman, Koplak, Setan, \\
& Dungu \\
& Ngotot \\
\hline
\end{tabular}

Afektif (affect) terkait dengan suka atau tidak suka dengan empat dimensinya kecondongan, kesukaan, keamanan, dan kepuasaan (Martin \& White, 2005: 51). Hampir semua ungkapan itu merupakan afek dalam dimensi kesukaan yang negatif (dislikeness atau unhappiness), ketidaksukaan, dari yang sekedar tidak suka hingga sangat tidak suka, dengan kata muak. Bila kita cermati publik banyak yang mengomentari AN dari aspek fisik, yang tentu saja tidak relevan dengan obyek debat itu sendiri. Kata-kata yang merujuk pada bagian tubuh seperti gigi, bacot, cocot, muka berantakan muncul berulang dari beberapa komentar.

Namun demikian komentar fisik tersebut tidak semata-mata karena bentuk fisik AN yang mengundang respon, tetapi lebih pada perilaku AN di sepanjang debat yang banyak melakukan interupsi, menyela dan memotong saat lawan bicara menggunakan jatah bicaranya. Sehingga muncul kata nyerocos (5), ngegas (5), motong (5), memotong (5), bacot (5) sebagai ketidakpuasan atau ketidaksenangan yang kemudian terlembaga menjadi bentuk penilaian bahwa perilaku tidak pantas. Artinya kritikan-kritikan yang mengarah pada bagian tubuh itu sebenarnya merupakan penilaian (judgement) terhadap 
perilaku (yang tidak baik), yang kemudian memicu relasi metaforis dengan bentuk-bentuk tubuh (yang kurang bagus).

Efek lanjutan dari sikap yang tidak baik atau kurang beretika tersebut adalah bahwa isi pembicaraan dari hasil menyerobot itu tidak bermutu, tidak sebanding dengan kandungan dan gaya bicara dari lawan debatnya, yang kebetulan seorang dokter. Ujungnya, AN seperti seorang pasien yang tengah berbicara dengan dokternya. Bahkan, ia disebut sebagai pasien sakit jiwa, yang diiringi dengan ucapan-ucapan emotif lain yang menunjukkan penilaian kapasitas yang negatif terhadapnya, koplak, dungu, preman, hingga setan. Ringkasnya, persepsi publik yang negatif justru digiring oleh perilaku AN yang tidak patut dan kurang etis, karena selalu memotong pembicaraan lawan bicaranya-dan apa yang disampaikan tidak berbobot di mata publik.

Dengan fakta obyektif yang demikian, publik dari kubu Jokowi pun tidak dapat berkomentar untuk membela atau mendukung secara lantang kepada Adian untuk "membalas" kata-kata pedas yang ditulis oleh publik yang tidak suka dengan perilaku AN dalam perdebatan itu. Beberapa komentar yang muncul hanya bernada datar, seperti mantap, keren, dan hebat dengan jumlah yang tidak banyak. Bahkan ada komentar yang lebih seperti pelarian dan tidak merujuk pada fakta obyektif dari acara debat di TV tersebut, "Bang Adian dapet amal banyak nih...dari yg maki-maki" atau menyampaikan pujian yang tidak berhubungan dengan materi yang dibicarakan, "berjuang melawan orba", sekedar mengingatkan bahwa AN adalah salah satu pejuang reformasi yang turut meruntuhkan rezim orde baru. Dengan kata lain, orang-orang ini tidak membantah secara frontal terhadap penilaian-penilaian dari publik yang menyatakan bahwa AN bersikap tidak etis, dan pembicaraannya kurang berbobot, sehingga memicu sikap-sikap negatif dari warga net. Penilaian dan afektif yang negatif terhadap AN tentu saja berbanding terbalik dengan komentar publik terhadap lawan bicaranya, Gamal Abinsaid, yang akan dibahas pada bagian selanjutnya.

\subsection{Persepsi Publik Terhadap Tokoh Pendukung Kubu 02}

Tokoh pendukung 02 yang cukup populer di masyarakat adalah Rocky Gerung (RG). Ia selalu mendominasi pembicaraan di media TV dengan kata-katanya yang "cerdas" dan "berani" dalam mengkritik pemerintahan atau kubu petahana. Namun demikian, kesan positif semacam itu tidak tampak saat ia beradu argumen dengan BS, dan hasilnya persepsi publik pun bergeser lumayan jauh dari sebelumnya. Hal ini setidaknya tergambar dari kumpulan komentar publik terhadap video terkait.

Gambaran komentar-komentar dari publik secara lebih konkret dapat dibaca dari beberapa sampel berikut. Dalam komentar 1, tampak jelas komentator mengolok-olok Rocky Gerung yang dianggap "dungu". Kata "dungu" adalah ungkapan yang biasa digunakan RG untuk labelisasi Jokowi dan tokoh-tokoh pendukungnya. Selain itu, orang yang sama juga mengapresiasi lawan bicara RG, Budiman Sudjatmika yang merupakan tokoh reformasi 98, sekaligus mempertanyakan RG di mana ketika peristiwa itu. Ia juga menegaskan kedigdayaan BS yang berhasil melengserkan rezim Soeharto. Artinya diktator saja dapat dikalahkan, apalagi sekedar orang sekelas RG.

\section{Komentar 1: Dialog bersama RG dan BS}

Org dungu sebenarnya ya si rocky ini, kliatan dungunya klo dah berhadapan dgn budiman, budiman sujadmiko pahlawan reformasi bro, soharto aja lengser, lah si gerung kemana 98?? 
Berikut gambaran sikap appraisal publik terhadap performance Rocky Gerung (RG) saat menghadapi Budiman Sudjatmika (BS). Deskripsinya mengikuti struktur dan lapisan penilaian yang mencakup afektif, judgement, dan apresiasi. Dalam kasus-kasus yang relevan, lapisan-lapisan dari ketiga unsur pun digunakan untuk membuat elaborasi yang lebih rinci terhadap kategori komentar yang ditulis oleh publik untuk menanggapi RG (Martin \& White, 2005: 53-55). Tampak dari aspek afektif, publik menyatakan ketidaksukaannya dengan kata-kata yang sangat keras, "mampus" - serapah yang menyatakan doa kasar agar obyeknya mati saja. Ungakapan tersebut menyatakan kebencian yang teramat sangat.

Tabel 3. Ungkapan persepsi publik terhadap Rocky Gerung

\begin{tabular}{lll}
\hline \multicolumn{1}{c}{ Afektif } & \multicolumn{1}{c}{ Penilaian } & \multicolumn{1}{c}{ Apresiasi } \\
Alangkah & Vicky prasetyo (6), bolot, tidak cerdas, mati kutu, & Narasi \\
malunya RG & peracun rakyat, dungu (10), kaleng, sensasi, & melompat- \\
Nggak ada & pembohong besar, mulut besar, cap dengkul, goblok, & lompat, \\
kontribusi, & tumpul, Tidak valid, tidak relevan, Bahaya & Subtansi \\
andil, nyali & & ngawang- \\
Mampus & & ngawang \\
\hline
\end{tabular}

Dilihat dari aspek penilaian (judgement), hampir semua ungkapan yang muncul merupakan bentuk deklarasi untuk menyatakan bahwa RG sebenarnya tidak pintar, tidak cerdas, dan justru sebaliknya. Padahal, selama ini dalam forum-forum media RG dikenal sangat pintar dan pandai menciptakan ekspresi-ekspresi smart untuk mengkritik jalannya pemerintahan Jokowi. Ia sering menjadi panel pakar untuk memberikan pencerahan tentang apa yang berlangsung atau terjadi dalam kabinet kerja pimpinan petahana. Pernyataan BS, lawan debatnya, yang menyatakan bahwa RG hanya bermain logika dan kata-kata, tanpa substansi, seperti membuat publik terbuka-utamanya publik pendukung capres petahana. Tampaknya, serangan BS tidak dapat dijawab secara baik oleh RG, sehingga komentar-komentar yang begitu negatif dan menyerang citra RG begitu deras menyeruak dalam kolom komentar tersebut.

Ungkapan emotif yang menyasar pada lapisan kapasitas RG pun teramat banyak, dari yang santun hingga yang paling kasar, tidak cerdas, mulut besar, tumpul, dungu, dangoblok. Kata-kata ini merupakan bentuk penilaian yang menyatakan bahwa subyek tidak memiliki kapasitas yang memadai (Martin \& White, 2005:54) untuk menjalankan tugasnya-dalam hal ini menjadi pengamat yang membela capres penantang. Kata dungu disebut hingga 10 kali; kata ini adalah ucapan yang biasa digunakan oleh RG untuk menyerang Jokowi dan orang-orang di kubu 01. Kata tersebut seakan menjadi bumerang bagi RG dalam situasi tersebut.

Selain itu, RG juga diserang dalam hal kelihaiannya bermain kata-kata, tetapi nyatanya tidak mampu melawan BS dan dinyatakan oleh BS belum atau tidak pernah menunjukkan kerja nyata bagi negara. Untuk predikat ini, publik menggunakan ungkapanungkapan seperti sensasi, mulut besar, pembohong besar, peracun rakyat, dan juga kaleng. Bahkan ia disamakan dengan pelawak Bolot, yang sering berpura-pura tuli dan pembicaraanya tidak nyambung dengan topik yang disampaikan oleh lawan tutur. Yang lebih parah lagi, RG disebut sebagai Vicky Prasetyo, selebritis karbitan yang suka menggunakan kata-kata sensasional tetapi artinya kosong-memilih kata-kata intelektual yang seringkali tidak sesuai dengan konteks. Penyebutan RG dengan Vicky ini muncul hingga 6 kali, dan terkadang publik menyebut dengan Rocky Prasetyo, dengan tujuan 
untuk menyamakan bahwa kapasitas pemikiran RG setara dengan selebritis yang suka omong kosong tersebut—dengan tujuan agar terlihat cerdas.

Penilaian-penilaian yang negatif dalam afektik dan judgement juga selaras dengan aspek apresiasi, yang menyoroti pernyataan-pernyataan RG secara obyektif. Disebutkan oleh salah seorang warga net, bahwa "Narasi" dari RG dinilai "melompat-lompat." Seorang audiens lain menambahkan bahwa kandungan dari apa yang disampaikan tidak substansial, "substansi ngawang-ngawang". Dua deskripsi tersebut jelas menyatakan apresiasi bahwa pembicaraan RG itu menghasilkan reaksi yang negatif, karena tidak menarik dan sulit dipahami oleh banyak orang, apresiasi: reaksi; sementara yang kedua merupakan bentuk apresiasi valuasi yang menyatakan bahwa muatan proposisi dari jawaban atau tanggapan RG atas serangan dari BS itu "dangkal", yang merupakan apresiasi: valuasi negatif (Martin \& White, 2005: 56). Apresiasi publik tersebut secara lengkap dapat dibaca dalam kutipan berikut.

edi simamora10 months ago

Analogi berpikir Gerung tidak logis dan cenderung tidak masuk akal. Pernyataan Gerung melompat-lompat sehingga Gerung tidak membahas hal yang substantif, tetapi hanya permukaan. Amat disayangkan Gerung tidak menggunakan metode empiris untuk membandingkan asumsi dan bukti, kecuali narasi yang melompatlompat...

fuad 988 months ago

bener, rocky cuma balik2in kata.. substansi mengawang2

Komentar yang pertama di atas terlihat cukup obyektif, dengan pilihan-pilihan kata yang akademis, bukan semata-mata menyalahkan, tetapi memberikan argumen yang cukup berterima dalam logika publik. Begitu pun dengan komentar kedua, walaupun hanya singkat, penulis menggarisbawahi apa yang diungkapkan oleh BS. Hal ini menandakan bahwa ungkapan-ungkapan emotif dari komentator memang tidak semata karena mereka tidak menyukai RG, tetapi memang fakta obyektif dari pernyataanpernyatan RG memang tidak logis-walaupun terkadang diungkapkan dengan muatan emosional yang kental, seperti dengkul, pembohong dan goblok.

Satu komentar yang berlawanan arah adalah komentar dialog antara Adian Napitupulu (AN) dengan Gamal Abinsaid (GA). Gamal mendapatkan penilaian yang positif dari publik, dan sebaliknya AN dipersepsikan secara negatif oleh kebanyakan dari mereka. Salah satu komentar yang paling menonjol adalah yang menyatakan bahwa perdebatan itu seperti pembicaraan antara seorang dokter dan pasiennya. Gamal memang seorang dokter, dan karena Adian dianggap kurang beretika dalam berdialog dengan sering memotong pembicaraan mitra tutur, ia disebut sebagai seorang pasien (bahkan sakit jiwa), yang sangat bernafsu untuk bicara.

\section{Komentar 2.}

a. Pas 6:o4 si adian malah main hp sendiri pas gamal ngomong, keliatan kalo gakmenghargai..dia aja gak bias beretika sama orang yg ngajak bicara kok nyalahin rakyat yg tdk menghargai presiden sebel gw lama"... yg punya kaca dong pinjemin si adiani tu heran $g w$

b. Bhahahaha keliatan Adian ngomong gak mikir 0 Debat macam apa itu Adian, motong2 pembicaraan orang. Koplak Pak Pak. Para penguasa haus jabatan, dasar penjilat. 
Jadi komentar-komentar memang lebih banyak dialamatkan pada AN, dengan reaksireaksi negatif. Tidak banyak komentar diarahkan pada Gamal seperti tampak pada Tabel 8, yang merangkum hampir seluruh ungkapan-ungkapan emotif yang ditulis dalam kolom komentar. Meskipun tidak banyak,

Tabel 4. Ungkapan persepsi publik terhadap Gamal Abinsaid

\begin{tabular}{|l|l|l|}
\hline \multicolumn{1}{|c|}{ Afektif } & \multicolumn{1}{|c|}{ Penilaian } & \multicolumn{1}{c|}{ Apresiasi } \\
\hline Salam & Debat dokter (3) dan pasien (3) sakit jiwa & Terlampau tinggi ilmu dan \\
Semoga selalu sehat & Argumen adian dipatahkan semua oleh dr & adamu \\
Semangat dok & gamal \\
gamal & Bro Gamal Albinsaid Smart person, for any & \\
Bro Gamal Albinsaid & ministry, & \\
$\begin{array}{l}\text { Dr. Gamal } \\
\text { amazing }\end{array}$ & Naik daun dr gamal & \\
& Mantap, dokter ganteng, cerdas & \\
\hline
\end{tabular}

unsur-unsur yang komentar yang muncul cukup variatif, walaupun sebagaimana terjadi pada komentar-komentar sebelumnya, hampir sebagian besar publik mengungkapkan appraisal dalam bentuk judgement. Pada kolom afektif, hanya ada satu kategori yang tampak yakni kebahagiaan:suka (Martin \& White, 2005:51) menunjukkan bahwa publik menyukai dan juga terkesan dengan penampilan dan kesabaran Gamal dalam menghadapi hujan interups lawan debatnya.

Nada serupa juga tampak pada kolom judgement. Ungkapan-ungkapan emotif yang bersifat positif banyak mengarah pada kapasitas, baik dengan sekedar menyebut profesinya, dokter, atau pun menggunakan labelisasi kapasitas secara intelektual, smart, cerdas atau pun dengan ungkapan tidak langsung "for any ministry" yang maksudnya bahwa dengan kapasitas kompetensi yang demikian Gamal pantas untuk menduduki jabatan menteri. Ungkapan penilaian tidak langsung juga terbaca dari komentar, "Argumen Adian dipatahkan semua oleh Gamal", yang secara tidak langsung menyatakan bahwa kapasitas kecerdasan dan keterampilan debat Gamal di atas AN, sehingga mampu mengalahkan argumen dan opini dari lawannya itu. Satu komentar pada kolom apresiasi menegaskan fakta tersebut, bahwa keduanya tidak imbang dalam hal kapasitas, yang memang merupakan bagian dari penilaian judgement (Martin \& White, 2005:53); Gamal digambarkan memiliki kapasitas yang positif sebagai sosok yang "educated", "competent", dan gagasan serta artikulasi yang "sound".

Meskipun demikian terdapat juga beberapa komentar bernada negatif terhadap penampilan Gamal. Komentar b dan c merupakan bentuk judgement yang mengkritik kapasitas Gamal, baik secara pendidikan dan pengalaman yang dianggap belum cukup memadai untuk masuk dalam dunia politik. Komentar ini sungguh dipaksakan; sikap mengalah dalam hal waktu bicara dianggap sebagai "kelemahan" (lembek). Sementara komentar a merupakan bentuk apresiasi negatif mempertanyakan pendapat Gamal tentang kapasitas capres yang harus kuat secara mental, dan tidak cengeng. Dengan kritikan yang datar semacam ini, persepsi publik secara umum terhadap penampilan Gamal dalam perdebatannya dengan Adian memang cenderung sangat positif.

Komentar 3.

a. Menghina presiden apakah layak disebut explorasi

b. Politik bukan tempatmu kawan

c. Pemain baru, terlalu lembek, gak sepadan 
Namun demikian, secara umum pihak petahana dapat dikatakan lebih berterima di mata dan hati publik masyarakat Indonesia, yang diwakili oleh para netizen yang memberikan komentar pada video di kanal-kanal Youtube. Gagalnya sang tokoh sentral dalam merebut komunitas netizen di forum media sosial tampaknya dapat menjadi petunjuk gambaran kemungkinan kemenangan atau kekalahan di kancah pemilu yang sebenarnya. Nyatanya persepsi publik dalam kajian ini membuktikan bahwa para tokoh dari petahana lebih disukai publik bila dibandingkan sosok-sosok dari pihak pesaing. Tentu saja, hal ini juga terkait dengan penggunaan bahasa sebagai sarana komunikasi sekaligus cerminan perilaku yang kemudian turut membentuk persepsi dalam pemikiran publik sebagai pemirsa baik melalui media TV atau pun kanal Youtube.

Secara umum persepsi publik terhadap masing-masing kubu tergambar dalam tabel 5. Bila dicermati publik (warga net, penulis komentar) secara umum memang sudah terpolarisasi pada pilihan 01 atau 02. Dengan posisi semacam ini mereka pun mengelompok dalam memberikan komentar apakah condong ke 01 atau ke 02. Akibatnya masing-masing memandang diri mereka dengan komentator lain yang sepaham dengan "us" (kami) dan melihat penulis komentar yang bernada berlawanan sebagai "them" (mereka).

Tabel 5

Persepsi publik terhadap wacana politik para tokoh

\begin{tabular}{|c|c|c|c|c|c|c|c|c|c|}
\hline \multirow[t]{2}{*}{ No } & \multirow[t]{2}{*}{ Tokoh } & \multicolumn{2}{|c|}{ Afektif } & \multicolumn{2}{|c|}{ Penilaian } & \multicolumn{2}{|c|}{ Apresiasi } & \multicolumn{2}{|c|}{ Total $(\%)$} \\
\hline & & + & - & + & - & + & - & + & - \\
\hline \multirow[t]{2}{*}{1} & BS & 8 & & 30 & & 5 & & 100 & 0 \\
\hline & RG & & & 1 & 78 & & & 1 & 99 \\
\hline \multirow[t]{2}{*}{2} & AN & 5 & 4 & & 51 & & & 8 & 92 \\
\hline & GA & 3 & 2 & 11 & 1 & & & 82 & 18 \\
\hline
\end{tabular}

Dalam situasi yang demikian, tumbuh secara natural strategi yang disebut oleh van Dijk (2001:103) sebagai "positive self-presentation and negative other presentation". Penulis komentar akan memberikan penekanan pada informasi-informasi yang baik tentang kubu yang didukung, dan juga menggembar-gemborkan hal-hal negatif tentang kubu lawan. Sebaliknya ia akan meminimalisir fakta-fakta negatif tentang calon yang didukung dan menutupi kebaikan-kebaikan dari kubu yang berseberangan.

Bila dicermati, yang paling dominan adalah strategi memberikan penekanan pada halhal negatif tentang pihak lawan, maka muncullah sebutan dan label negatif terhadap tokoh-tokoh yang mereka tonton, seperti goblok, bacot, preman, dungu, sakit jiwa, otak dengkul dan semacamnya, yang bertujuan untuk merendahkan kapasitas intelektual dari tokoh politik terkait. Kecenderungan semacam ini berlaku sama baik di kalangan pendukung kubu petahana maupun kubu penantang. Pilihan-pilihan kata dan juga bahasa dalam komentar memperlihatkan bahwa mereka berasal dari latar belakang yang beragam, baik dari tingkat pendidikan maupun kelas sosialnya-seperti tampak dari komentar yang terkadang ilmiah dan obyektif, tetapi juga ada yang kasar dan hanya berisi kata-kata serapah.

Strategi wacana van Dijk (2001) tersebut sebenarnya merupakan fenomena yang "alamiah" dalam kehidupan sosial. Strategi itu pun dikenal dan menjadi budaya bahasa di masyarakat Jawa dengan sebutan, "bebek ya silem; dhewek ya dialem"-yang setara 
dengan positive self-representation. Demikian juga kita mengenal peribahasa serupa dalam budaya nusantara, yakni "Semut di seberang lautan tampak, gajah di pelupuk mata tidak kelihatan", yang senada dengan negative other representation. Dari analisis appraisal publik di atas, kita dapat merasakan bahwa mereka akan mengabaikan kejelekan dari calon yang didukungnya, dan sebaliknya akan menyorot tajam hal-hal negatif mengenai calon lawan.

Meskipun strategi tersebut memang nyata adanya, publik juga tidak semata-mata dikendalikan oleh perspektif subyektif mereka. Obyek yang berupa penampilan para tokoh dalam debat politik tetap menjadi pertimbangan utama dan menjadi penentu persepsi mereka. Hal ini terbukti dari komentar-komentar negatif dari satu pihak hampir tidak pernah "dilawan" secara langsung atau dibantah oleh kubu lawan. Seperti tampak dari komentar yang menyatakan RG sebagai "Vicky Prasetyo", atau ketika AN disebut "banyak bacot, nyerocos", tidak ada komentar yang sekubu untuk membela tokoh yang didukung, karena fakta-fakta dalam debat memang merepresentasikan label-label tersebut. Begitu halnya, ketika BS dipuja-puja sebagai "legenda reformasi" dan GA disebut "ganteng, dokter", pihak lawan pun menerima begitu saja klaim-klaim tersebut; karena faktanya memang demikian. Artinya, meskipun publik menggunakan strategi "bebek silem", mereka tetap obyektif dalam memberikan penilaian sesuai penampilan para tokoh dalam kancah debat itu. Mereka berupaya membela tokoh-tokoh dan kubu yang didukung, tetapi mereka tetap "waras" dan tidak semata-mata mengenakan "kacamata kuda".

\section{SIMPULAN}

Analisis data memperlihatkan bahwa appraisal yang paling dominan adalah judgment (86\%), dan yang kedua adalah affect (11\%). Hal ini memperlihatkan bahwa publik secara mudah menjatuhkan penilaian terhadap tokoh-tokoh tersebut dari aspek individunya, baik secara positif maupun negatif. Hanya sebagian kecil publik $(2,5 \%)$ yang memberikan penilaian dengan menyoroti cara mereka berargumen, apresiasi. Bila dibandingkan, penilaian negatif dan positif terhadap wakil kubu 01 maupun 02 dari data-data ini cenderung seimbang. Namun, dicermati secara lebih dekat, kubu 01 memperoleh persepsi yang lebih baik; BS mendapatkan penilaian 100\% positif, sementara AN masih memperoleh nilai positif (8\%). Di pihak 02, GA hanya mendapatkan nilai positif maksimal $82 \%$, sementara RG hanya dapat poin plus $1 \%$. Bila dilihat dari strategi wacana, publik lebih cenderung menerapkan strategi "menekankan" hal-hal yang negatif dari tokoh-tokoh kubu lawan. Tentu saja, temuan ini tidak bisa menjadi dalil yang dapat digeneralisir karena terbatasnya data yang dikumpulkan. Setidaknya, hal ini sedikit menggambarkan faktor di balik kemenangan petahana di pilpres 2019.

\section{DAFTAR PUSTAKA}

Chalimah, Djatmika, Santosa, Riyadi \& Wiratno, Tri. (2018). Evaluating attitudes in news text: appraisal in critical discourse study. Advances in Social Science, Education and Humanities Research, volume 166. Atlantis Press.

Fairclough, Norman. (2001). Critical discourse analysis as a method in social scientific research in Methods of Critical Discourse Analysis (Ruth Wodak and Michael Meyer - editors). London: SAGE Publication Ltd.

Goatly, Andrew. (2007). Metaphor and Ideology. Ilha do Desterro Florianópolis no 53 p.063-093 jul./dez.2007.

Halliday, M.A.K. \& Mathiessen, Christian. (2004). Introduction to Functional Grammar (3rd Edition). London: Hodder Arnold. 
Kamal, Mustofa Riyadi Santosa, Djatmika. (2017). The imbalance attitude of the journalists in chemical castration texts: an SFL critical discourse analysis. Humaniora Vol. 29. No 2. Oktober 2017. Yogyakarta: FIB, Universitas Gadjah Mada.

Kress, Gunther \& Leeuwen, Theo van. (2006). Reading images: the grammar of visual design (edisi ke-2). London \& New York: Routledge Tayler and Francis e-Library.

Martin, J.R. \& White, P.R.R. 2005. The language of evaluation: appraisal in English. New York: Palgrave Macmillan.

Sudaryanto. (2015). Metode dan aneka teknik analisis Bahasa. Yogyakarta: Sanata Dharma Univ. Press.

Sukma, Bayu Permana. (2018). Sistem appraisal pada slogan dalam kain rentang kampanye politik bakal calon kepala daerah Kabupaten dan Kota Bogor, Ranah: Jurnal Kajian Bahasa, 7 (2), 132-145. doi: https://doi.org/10.26499/rnh.v7i2.603

VanDijk, Teun A. 2001. Multidisciplinary CDA: a plea for diversity in Methods of Critical Discourse Analysis (Ruth Wodak and Michael Meyer - editors). London: SAGE Publication Ltd. 